\title{
Novel Nanodispersed Coal Liquefaction Catalysts: Molecular Design Via Microemulsion- Based Synthesis
}

\author{
Technical Progress Report \\ July - September 1991
}

by

K. Osseo-Asare, E. Boakye, N. Vaidyanathan and L. R. Radovic

Department of Materials Science and Engineering

The Pennsylvania State University

University Park, PA 16802

Date Published, October 1991

Prepared for the United States

Department of Energy

Under

Contract No. DE-AC22-90PC90054

\section{MASTER}


Novel Nanodispersed Coal Liquefaction Catalysts:

Molecular Design Via Microemulsion-Based Synthesis

\author{
Technical Progress Report
}

July - September 1991

\author{
by \\ K. Osseo Asare, E. Boakye, N. Vaidyanathan and L. R. Radovic \\ Department of Materials Science and Engineering \\ The Pennsylvania State University \\ University Park, PA 16802
}

\title{
DISCLAIMER
}

\begin{abstract}
This report was prepared as an account of work sponsored by an agency of the United States Government. Neither the United States Government nor any agency thereof, nor any of their employees, makes any warranty, express or implied, or assumes any legal liability or responsibility for the accuracy, completeness, or usefulness of any information, apparatus, product, or process disclosed, or represents that its use would not infringe privately owned rights. Reference herein to any specific commercial product, process, or service by traúe name, trademark. manufacturer, or otherwise does not necessarily constitute or imply its endorsement, recom. mendation, of favoring by the United States Govermment or any agency thereol. The views and opinions of authors expressed herein do not necessarily state or reflect those of the United Stales Government of any agency thereof.
\end{abstract}

October 1991 


\section{DISCIJAIMER}

This report was prepared as an account of work sponsored by an agency of the United States Government. Neither the United States Government nor any agency thereof, nor any of their employees, makes any warranty, express or implied, or assumes any legal liability or responsibility for the accuracy, completeness, or usefulness of any information, apparatus, product, or process disclosed, or represents that its use would not infringe privately owned rights. Reference herein to any specific commercial product, process, or service by trade name, trademark, manufacturer, or otherwise does not necessarily constitute or imply its endorsement, recommendation, or favoring by the United States Government or any agency thereof. The views and opinions of authors expressed herein do not necessarily state or reflect those of the United States Government or any agency thereof. 


\section{TABLE OF CONTENTS}

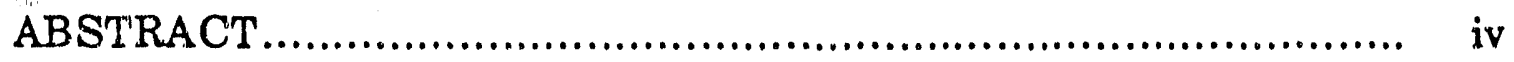

PROJECT OBJECTIVES.................................................. 1

STATEMENT OF WORK ................................................. $\quad 2$

DESCRIPTION OF TECHNICAL PROGRESS ............................. 6

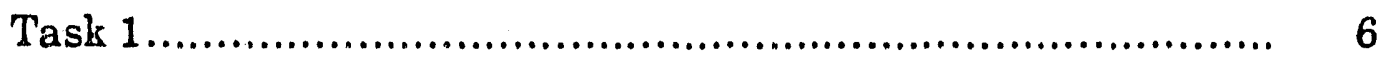

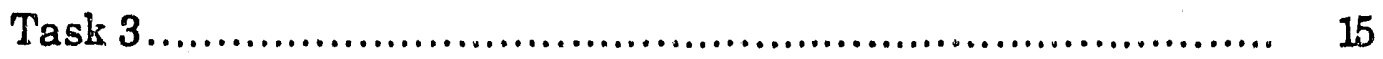

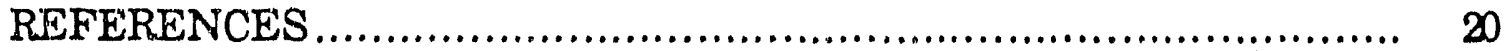




\begin{abstract}
Further progress has been made in the preparation of microemulsionbased molybdenum sulfide catalysts as well as in our understanding of the surface chemistry of the molybdenum/coal system. Preliminary liquefaction tests show relatively high yields of oils at very low catalyst loadings.
\end{abstract}




\section{PROJECT OBJECTIVES}

The objective of this project is to pursue the development of highly dispersed and inexpensive catalysts for improved coal solubilization and upgrading of coal liquids. A novel study of the synthesis of liquefaction catalysts of nanometer size will be carried out. It is based on the molecular design of reverse micelles (microemulsions). These surfactant-stabilized, metalbearing microdrops offer unique opportunities for synthesizing very small particles by providing a cage-like effect that limits particle nucleation, growth and agglomeration. The emphasis will be on iron- and molybdenum-based catalysts, but the techniques to be developed should also be generally applicable. The size of these very small and monodispersed particles will be accurately determined both separately and after in situ and ex situ coal impregnation. The as-prepared nanoparticles as well as the catalyst-impregnated coal or char matrix will be characterized using the following techniques: dynamic light scattering, $x$-ray diffraction, x-ray photoelectron spectroscopy, scanning and/or transmission electron microscopy, and selective chernisorption. Catalytic activity tests will be conducted under standardized conditions in both hydrogenation and hydrodesulfurization reactions. The effect of particle size of these unsupported catalysts on the product yield and distribution during liquefaction of a bituminous and a subbituminous coal will thus be quantitatively determined. 


\section{STATEMENT OF WORK}

The following task activities are being carried out under this project.

\section{Task 1: Formulation, Characterization and Synthesis (Catalyst Preparation)}

\section{Subtask 1.1: Microemulsion Formulation and Characterization}

We shall formulate and characterize suitable microemulsion media wherein the catalyst particles shall be synthesized. Different surface-active agents shall be considered. These shall include ionic and nonionic systems as well as mixtures of surfactants. The use of cosurfattants and additives shall also be investigated. Special emphasis shall be given to the characterization of microemulsions formulated with polynuclear aromatic compounds (model coal liquefaction solvents) as the external nonpolar phase.

The selection of suitable surfactant systems and characterization methods shall be based on well-documented information in the literature. For example, the phase diagrams shall be based on data obtained by accepted titration techniques. At a minimum, we shall use the techniques of steady-state fluorescence spectroscopy, fluorescence lifetime measurements and dynamic light scattering for the determination of microemulsion structural and dynamic properties. Using the fluorescence techniques, the surfactant aggregation numbers and rates of intermicellar exchange shall be 
determined. We shall use light scattering techniques to determine the droplet size, polydispersity and intermicellar interactions. In addition, we shall determine the particle size of the nanoparticles produced.

\section{Subtask 1.2: Catalyst Synthesis}

In this subtask, the focus shall be on the preparation of $\mathrm{Fe}$ and Mo sulfide nanosize particles. The particles shall be synthesized in microemulsion media using the following techniques:

(a) mixing two microemulsions containing the metal ion ( $\mathrm{Fe}, \mathrm{Mo})$ and $\mathrm{S}$ anion, respectively;

(b) bubbling $\mathrm{H}_{2} \mathrm{~S}$ through a microemulsion containing the metal ions;

(c) solubilizing both the metal ion and the sulfur-bearing reactant in a microemulsion and inducing the reaction by thermal decomposition of the sulfur donor.

Incorporation of the catalyst particles into the coal matrix shall be achieved using both ex situ and in situ techniques. The ex situ techniques shall involve the impregnation of the coal matrix with nanoparticles prepared by one of the routes described in Subtask 1.1. If the solvent used as the external phase in the microemulsion synthesis does not have the desired wetting characteristics, experiments shall be conducted using particles resuspended in a suitable solvent. By in situ technique is meant catalyst synthesis and incorporation into the coal matrix in a single step. One of the in situ methods shall involve impregnation of a coal with a metal-ion/sulfur- 
donor-loaded microemulsion, followed by heat treatment to promote metal sulfide formation. Other in situ methods shall be attempted to identify the best technique to obtain a coal matrix incorporating homogeneously distributed nanosize catalyst particles.

\section{Task 2: Catalyst Characterization}

A detailed characterization of the catalyst materials produced in Task 1 shall be performed using the following techniques: dynamic light scattering, UV/visible absorption and fluorescence spectroscopies, $x$-ray diffraction (XRD), x-ray photoelectron spectroscopy (XPS), scanning and/or transmission electron spectroscopy (SEM/TEM), Mössbauer effect spectroscopy (MES), and selective chemisorption.

For particles developed by ex situ techniques, particle size and size distribution shall be determined prior to impregnation into the coal matrix. The change in particle size after introducing the particles into the coal matrix shall be determined. The particle size and particle size distribution after in situ impregnation shall be determined. In order to better assess the characterization technique, a limited number of experiments shall be performed on catalyst particles impregnated onto the char derived from the parent coal. 


\section{Task 3: Catalyst Testing}

Liquefaction tests shall be carried out in stainless steel tubing bomb reactors under standard conditions: $275-400^{\circ} \mathrm{C}, 7 \mathrm{MPa} \mathrm{H}_{2}$ (cold), $30 \mathrm{~min}$. Both a hydrogen-donor solvent (e.g., tetralin) and a non-donor solvent (e.g., saphtalene) shall be used. The solvent/coal ratio shall be $2 / 1$. For each catalyst developed in Task 1 , liquefaction tests shall be conducted on one bituminous and one subbituminous coal. The coals chosen (with the concurrence of the DOE Project Manager) shall have a sufficiently extensive liquefaction database to permit a meaningful evaluation of the catalysts developed in Task 1 . If requested by the DOE Project Manager, samples (up to 5 grams) of catalyst or catalyst-impregnated coal will be provided for indeperdent testing.

A limited number of gasification experiments on catalyst-impregnated coal shall be performed to provide a measure of the coal/catalyst interface area. In selected cases, the kinetics of hydrodesulfurization of a model compound shall be determined to provide a relative comparison of the effectiveness of the catalysts developed in Task 1 in coal dissolution vs. liquid upgrading. 


\section{DESCRIPTION OF TECHNICAL PROGRESS}

\section{Task 1: Catalyst Preparation}

\subsection{Particle Synthesis in Microemulsions}

This portion of the quarterly report summarizes the synthesis of molybdenum sulfide in the NP-5/tetralin/benzyl alcohol/water microemulsion system. Tetralin has been used as the oil phase in the microemulsion formulation because it serves as a model hydrogen-donor solvent for coal liquefaction. Advantage has been taken of the following microemulsion properties to make particles of different sizes:

(i) water-to-surfactant molar ratio;

(ii) ion occupancy number.

Our ultimate aim is to verify the existence of a relationship between catalyst particle size and liquefaction yields.

The non-ionic surfactant polyoxyethylene (5) nonylphenyl ether (NP. 5) was obtained from GAF Chemical Corporation and was used as received. Ammonium tetrathiomolybdate (99.97\%) and 1,2,3,4-tetrahydronaphtalene (tetralin) were obtained from Aldrich. Benzyl alcohol was obtained from Eastman Kodak Company. Before use, tetralin was dried with molecular sieves. Reverse microemulsions were prepared at room temperature by adding $10 \%$ sulinuric acid to a solution of $0.2 \mathrm{M}$ or $0.4 \mathrm{M} \mathrm{NP}-5 /$ tetralin/benzyl alcohol. The weight and molar ratios of benzyl alcuhol to NP-5 were 2.5 and 9.9 , respectively. The acid-solubilized microemulsion was deoxygenated for 20 minutes by purging with nitrogen prior to the addition of $1 \times 10^{-2} \mathrm{M}$ ammonium tetrathiomolybdate (ATTM) at $50^{\circ} \mathrm{C}$. Nitrogen was further 
bubbled while molybdenum trisulfide was precipitating according to the reaction:

$$
\mathrm{MaS}_{4}{ }^{2-}+2 \mathrm{H}^{+}=\mathrm{MoS}_{3}+\mathrm{H}_{2} \mathrm{~S}
$$

Samples for transmission electron microscopy (TEM) analysis were obtained by dipping carbon-coated copper grids into the dispersions and drying at room temperature. Pricr to sample extraction, each sample bottle was sonicated for $1 \mathrm{~min}$. Particle sizes was determined using a Philips 420 transinission electron microscope operating at $120 \mathrm{kV}$, with a resolution of about $0.6 \mathrm{~nm}$. The diameters of at least 300 particles were measured for each sample to obtain an average particle diameter and standard deviation.

In the previous quarter, the synthesis of molybdenum sulfide in 0.1 M NP-5/cyclohexane microemulsion was reported. A new microemulsion system using tetralin as the continuous oil phase has been formulated now. This new method has a potential advantage for coal liquefaction in that tetralin is a good solvent for the coal liquefaction process and hence the need to harvest the particles can be avoided. Figures 1 and 2 respectively show the TEM micrograph of molybdenum sulfide in $0.2 \mathrm{M}$ NP5/tetralin/benzyl alcohol microemulsion and a plot of the average particle size vs. the water-to-surfactant molar ratio $(R)$ for molybdenum sulfide in the $0.4 \mathrm{M} \mathrm{NP-5/tetralin/benzyl} \mathrm{alcohol} \mathrm{microemulsion.} \mathrm{Ir} \mathrm{the} \mathrm{latter,} \mathrm{the}$ particle size decreases with an increase in $R$ to a value of 2 and then increases with $R$. Also the polydispersity increases with $R$. Similar trends have been reported in the literature for microemulsion-mediated synthesis of CdS (Lianos and Thomas, 1988; Petit and Pileni, 1988; Modes and Lianos, 1989; Towey et al., 1990). Using a fractal model, Modes and 


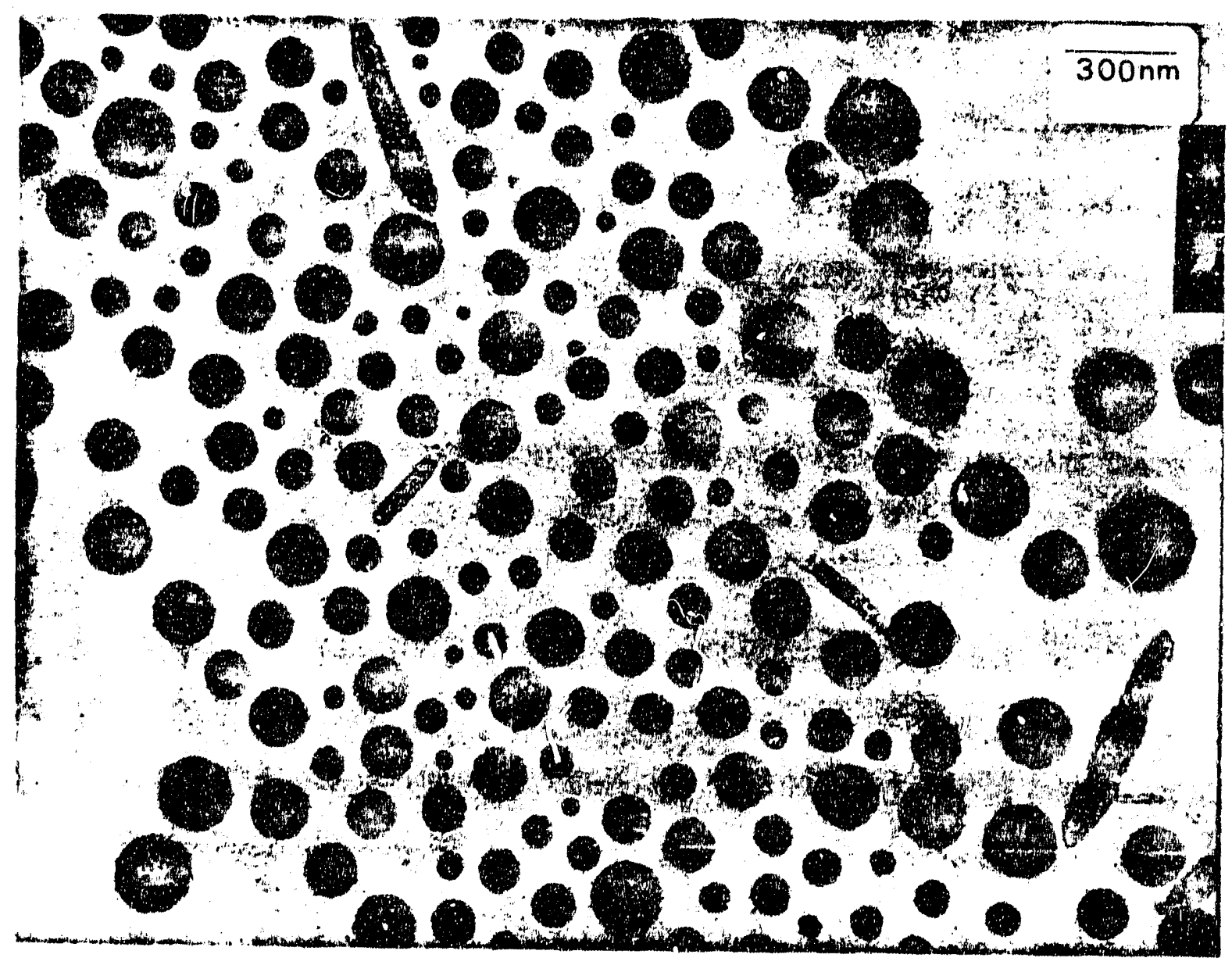

Figure 1. TEM micrograph of molybdenum sulfide in $0.4 \mathrm{M} \mathrm{NP}$. 5/tetralin/benzyl alcohol microemulsion $(R=3$ ). 


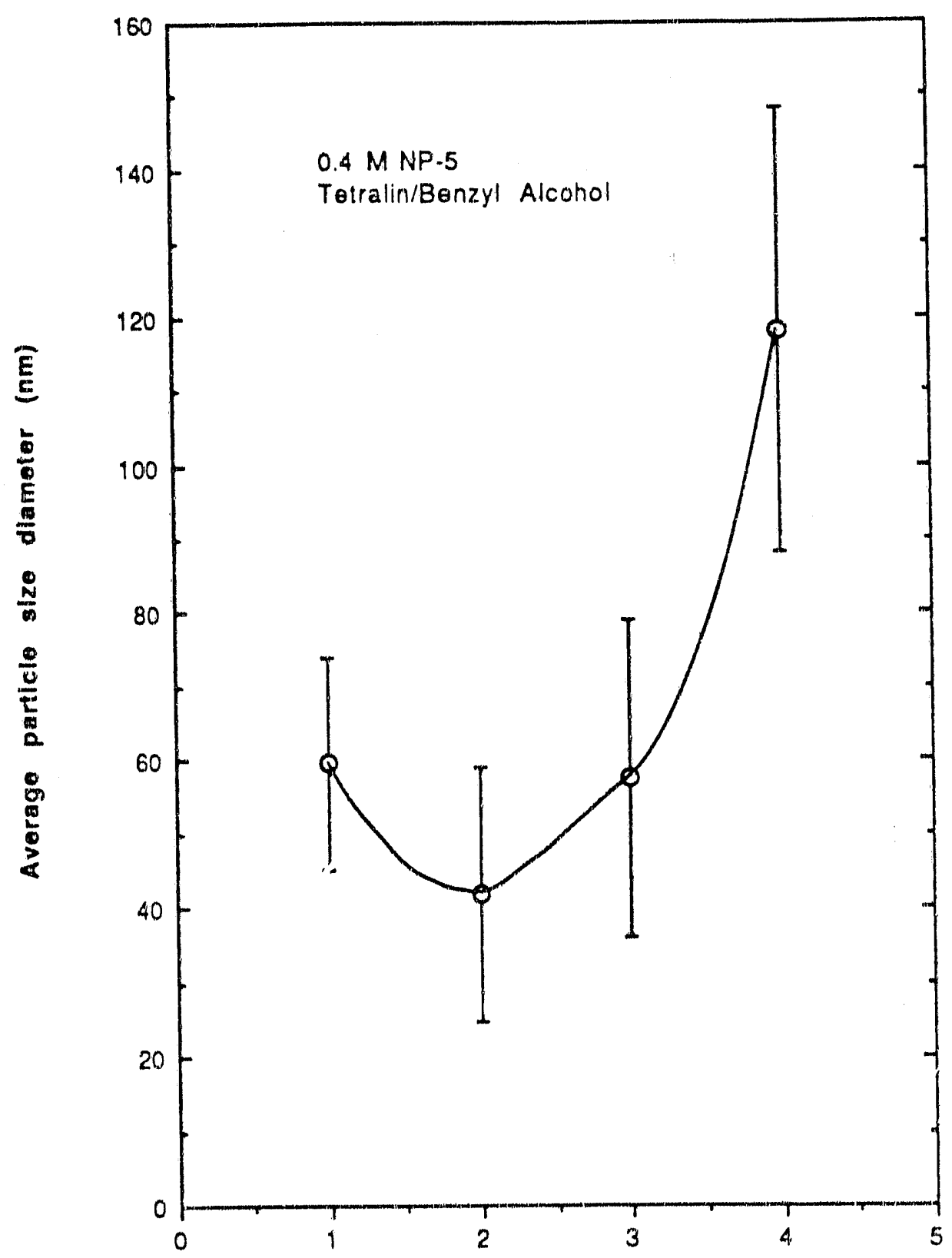

R (mole of waterimole of suptactant)

Figure 2. Effect of water-to-surfactant molar ratio (R) on average particle size for the $0.4 \mathrm{M} \mathrm{NP}-5 /$ tetralin/benzyl alcohol microemulsion. 
Lianos (1989) showed that polydispersity should increase with $R$. This is in accordance with the fact that the fluidity of the interface between the continuous oil phase and the reverse micelles increases with the water-tosurfactant molar ratio. Hence the rate of exchange of solubilizates between reverse micelles increases as the water-to-surfactant molar ratio is increased. The trends in this study may be rationalized by considering particle nucleation and growth in relation to the ion occupancy number (i.e., the number of reactant species in an reverse micelle). As $R$ increases, the surfactant aggregation number increases and hence the micellar concentration decreases. This corresponds to an increase in the ion occupancy number if the concentration of the reactant species in the microemulsion is constant. In this study, the concentration of the reactant species in the microemulsion was increased with $R$. Thus two factors contributed simultaneously to the increase in the ion occupancy number. First, the ion occupancy number increases with $R$ for a constant concentration of reactant species, as reported by Lianos and Thomas (1988). Second, the ion occupancy number will increase with increasing concentration of reactant species in the microemulsion, as reported by Nagy (1989), when nickel boride particles were synthesized in the $\mathrm{CTAB} /$ hexanol/water microemulsion. Molybdenum sulfide will form when $\mathrm{MoS}_{4}{ }^{2-}$ and $\mathrm{H}^{+}$ions find themselves in the same reverse micelle. The probability of such an encounter increases as the ion occupancy number increases, and this will increase the number of nuclei in the reverse micelles.

As discussed in an earlier report, the process of particle formation from dissolved ions can be represented in the following order: ions ..> monomers $\rightarrow>$ nuclei $-\rightarrow>$ particles. Once a stable nucleus is formed, it can 
grow by incorporating ions and monomers in solution. In order to form a stable nucleus, a cluster containing a critical number of monomers must form. The monomers are formed from the thiomolybdates and the proton in solution. A nucleus is formed if the ion occupancy number is greater than NC. From the classical nucleation theory, the higher the nucleation rate, the greater the number of nuclei and the smaller the particle size will be (Nagy, 1989). Thus, according to nucleation theory, the minimum particle size at $R=2$ corresponds to the maximum number of nuclei that transforms into primary particles. Here a distinction should be made between primary particle size and final particle size. The final particle size refers to the particle size after growth. Although the number of nuclei increases with $R$, the number of excess ions and monomers not utilized in nuclei formation will also increase with $R$. The excess ions and monomers will contribute towards growth via the rapid coagulation mechanism, as proposed by Towey et al. (1990). Thus from the plot of average particle size vs. $R$, one can infer that the contribution of the excess ions and monomers to growth for the final particle size takes effect at $R$ values of 3 and 4 . Ostwald ripening (dissolution of small particles and growth of larger particles at the expense of smaller ones) may also be taking place.

In summary, molybdenum sulfide particles have been synthesized in the 0.4 M NP-5/ tetralin/benzyl alcohol/water microemulsion system with $R$ values of 1-4. Such synthesis of molybdenum sulfide may have important technological applications: for now, at least, testing of the catalyst can be done without harvesting the particles. The variation of particle size caused by changes in the water-to-surfactant molar ratio has been explored in an attempt to make particles of desired size for coal liquefaction. Initial catalytic liquefaction tests using very low molybdenum logdings (see Section 
3.2) have given high yields of hexane-soluble liquids (oils); furthermore, the yield of oils appears to be inversely proportional to the size of the microemulsion-based particles.

\subsection{Molybdenum Adsorption on Coal}

Generally speaking, the issue of the effect of coal's surface chemistry on the effectiveness of Mo catalyst impregnation has been neglected in the literature. Figure 3 shows the results of the kinetics of Mo uptake from a $10^{-3} \mathrm{M}$ solution of ammonium heptamolybdate, at different levels of solution acidity. Relatively fast uptake in the first hour is seen to be followed by continued slow adsorption, probably due to the microporous nature of coal. As expected, higher uptakes of the anionic Mo species are observed in more acidic media, when the surface of this (subbituminous) coal is, on balance, positively charged (Solar et al., 1990). Addition of ammonium hydroxide to adjust the $\mathrm{pH}$ resulted in a color change of the filtrate: at $\mathrm{pH}=8$, it was light brown; at $\mathrm{pH}=10$, it was dark brown and darker still as the $\mathrm{pH}$ is increased further. Upon acidification, no precipitation occurs, suggesting that the brown color was not due to dissolved humic acids in the coal. Figure 4 confirms the above mentioned trend, in the $\mathrm{pH}$ range 2-8. It is intriguing to note, however, an apparent increase in Mo uptake in highly basic solution. (Its reproducibility and implications will be investigated further.) 


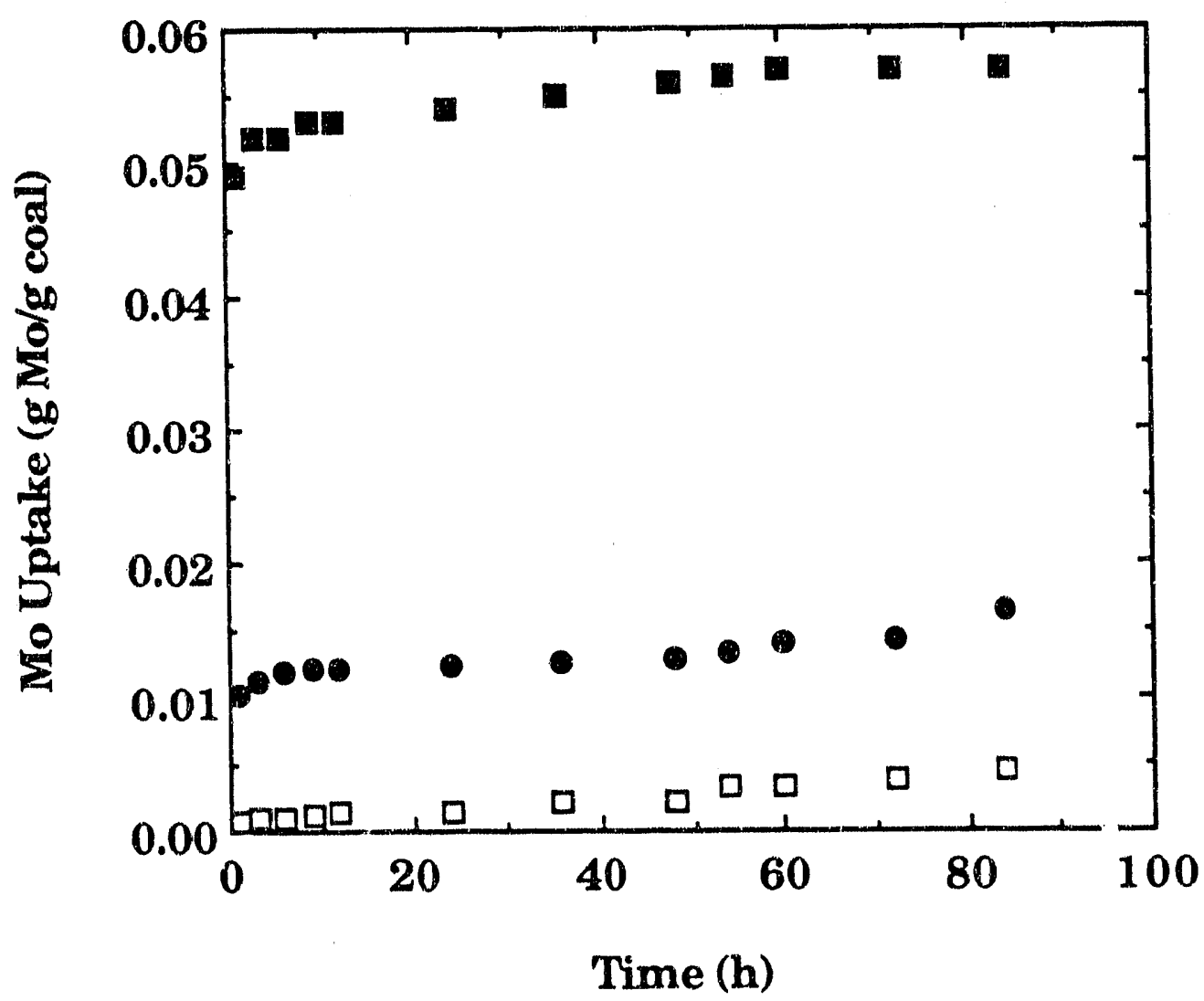

Figure 3. Kinetics of adsorption of molybdenum on the Wyodak subbituminous coal (PSOC 1.401) from $10^{-3} \mathrm{M}$ solution of ammonium heptamolybdate: $\square, \mathrm{pH}=8 ;-\mathrm{pH}=10 ; \mathbf{p H}=2.5$. (The $\mathrm{pH}$ was adjusted by addition of arnmonium hydroxide or formic acid.) 


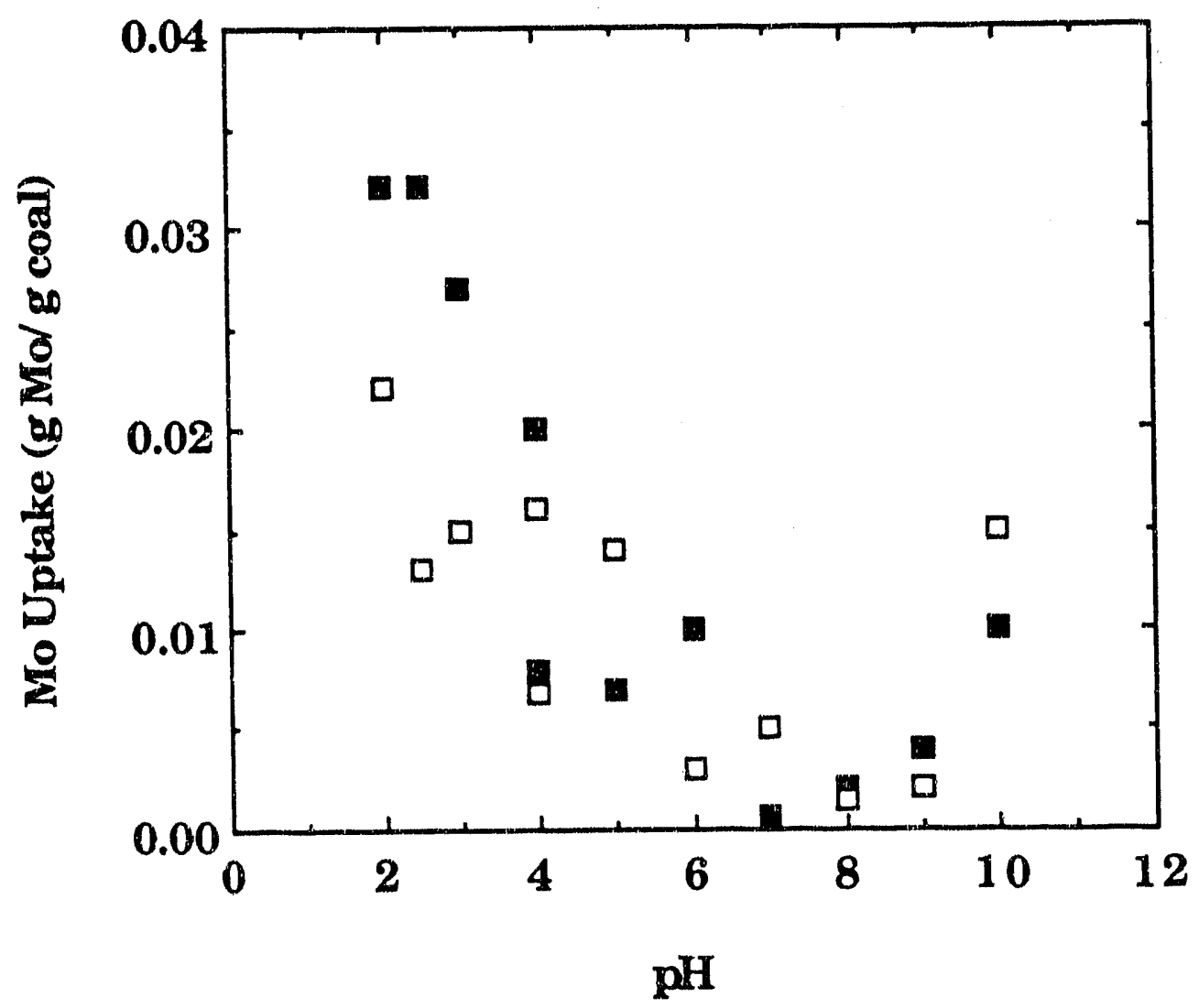

Figure 4. Effect of $\mathrm{pH}$ on the equilibrium adsorption of molybdenum on the Wyodak subbituminous coal (PSOC 1401): Mo uptake determined by atomic absorption spectroscopy of the filtrate; $D$, Mo uptake determined by ash analysis. 


\section{Task 3: Catalyst Testing}

\subsection{Microemulsion Catalyst Preparation}

The microemulsion-based catalysts were prepared in two batches, as described in Task 1. The two types were the $0.1 \mathrm{M} \mathrm{NP-5/cyclohexane} \mathrm{system}$ and the $0.4 \mathrm{M} \mathrm{NP}-5 /$ tetralin system. In the former case, the microemulsion was added to 2.5 grams of coal; tetralin was not used as the solvent, in contrast to the preparation procedure described in our previous quarterly report for the AOT/decane system. In the latter case, the (tetralincontaining) microemulsion was simply added to $2.5 \mathrm{~g}$ of coal in the tubing bomb reactor. "Blank" microemulsions, without the catalyst, were also prepared.

\subsection{Coal Liquefaction Experiments}

The standardized liquefaction tests were described in detail in our previous reports. The conditions were the following: $350^{\circ} \mathrm{C}, 30 \mathrm{~min} ; 1000 \mathrm{psig} \mathrm{H}_{2}$. Table 1 shows the yield of oils (plus gas) in liquefaction tests using the $0.1 \mathrm{M}$ NP-5/cyclohexane microemulsion for $R$ values of 0.5-3.0. At comparable Mo loadings, the yields are lower than for the NP-5/AOT microemulsion system (34-48\% oils + gas), possibly due to the absence of a hydrogen donor solvent.

Table 2 illustrates the use of NP.5/tetralin microemulsions for $R$ values of 1.0 and 2.0. The oil (plus gas) yield is seen to be remarkably high at low Mo loadings. Furthermore, a comparison with the data in Figure 2, 
Table 1

Results of Liquefaction Tests Using 0.1 M NP-5/Cyclohexane Microemulsion (ME) Molybdenum Sulfide Catalyst

\begin{tabular}{|c|c|c|c|c|}
\hline Run \# & Sample & $\begin{array}{c}\text { Mo } \\
\text { Loading }\end{array}$ & $\begin{array}{c}\text { Yield of Oils } \\
(+ \text { Gas }), \%\end{array}$ & $\%$ Residue a \\
\hline 17 & Coal/Mo ME $(\mathrm{R}=0.5)$ & $1.9 \mathrm{ppm}$ & 14.1 & 85.9 \\
\hline 18 & Coal/Mo ME $(\mathrm{R}=1)$ & $2.0 \mathrm{ppm}$ & 19.9 & 80.1 \\
\hline 19 & Coal/Mo ME $(\mathrm{R}=2)$ & $2.0 \mathrm{ppm}$ & 20.5 & 79.5 \\
\hline 20 & Coal/Mo ME $(\mathrm{R}=3)$ & $1.9 \mathrm{ppm}$ & 14.4 & 85.6 \\
\hline 21 & Coal/ME b & $0.0 \mathrm{ppm}$ & 4.6 & 95.4 \\
\hline
\end{tabular}

a Includes preasphaltenes and asphaltenes

b Surfactant plus cyclohexane alone.

\section{Table 2}

Results of Liquefaction Tests Using 0.4 M NP.5/Tetralin Microemulsion (ME) Molybdenum Sulfide Catalyst a

\begin{tabular}{|c|c|c|c|c|}
\hline Run \# & Sample & $\begin{array}{c}\text { Mo } \\
\text { Loading }\end{array}$ & $\begin{array}{c}\text { Yield of Oils } \\
\text { (+Gas), \% }\end{array}$ & \% Residue a \\
\hline 23 & Coal/Mo ME $(\mathrm{R}=1)$ & $58 \mathrm{ppm}$ & 78.4 & 21.6 \\
\hline 24 & CoalMo ME $(\mathrm{R}=2)$ & $118 \mathrm{ppm}$ & 83.2 & 16.8 \\
\hline 29 & Coal/ME $(\mathrm{R}=1)$ & $0.0 \mathrm{ppm}$ & 7.3 & 92.7 \\
\hline 30 & CoalME $(\mathrm{R}=2)$ & $0.0 \mathrm{ppm}$ & 5.2 & 94.8 \\
\hline
\end{tabular}

a Coal/tetralin $=1 / 2.5-2.6$

bIncludes preasphaltenes and asphaltenes 
as well as those in Table 1, suggests that there is an optimum water-tosurfactant ratio for which the average particle size is at a minimum and the yield of oils at a maximum. (The oils produced are relatively viscous, suggesting that they contain some higher-molecular-weight (hexanesoluble) components.) Preliminary tests indicate that for the NP$5 /$ cyclohexane system, beyond $R=2$ the yield of oils decreases precipitously.

Table 3 was compiled in an attempt to place our initial results into proper perspective. For a subbituminous coal, high oil yields were obtained by Weller and Pelipetz (1951), when the catalyst precursor was added to the coal in an acidic medium. This could be due either to the favorable interaction with the coal (see Section 1.2) or to a more effective sulfidation of the catalyst.

Hirschon and Wilson (1991) have recently reported relatively high yields $(\sim 84 \%)$ of toluene-solubles (corresponding roughly to the sum of asphaltenes, oils and gases) for an Illinois No. 6 bituminous coal $\left(425^{\circ} \mathrm{C}\right.$, $500 \mathrm{psi} \mathrm{H}_{2}, 20 \mathrm{~min}$ ) using an organometallic Mo complex, with $0.6 \mathrm{mmol}$ Mo/g coal, i.e., $5.8 \% \mathrm{Mo}$. The use of an organometallic Fe complex resulted in yields of $\sim 40 \%$ (in the absence of a hydrogen donor solvent), with $-3.4 \%$ Fe. Also using "dispersed-phase" Mo catalysts (1000 ppm of ATTM, MoS AHM), Utz et al. (1989) obtained yields of $\leq 60 \%$ heptane-solubles for a bituminous coal $\left(425^{\circ} \mathrm{C}, 1000 \mathrm{psi} \mathrm{H}_{2}, 1 \mathrm{~h}\right.$ ). Similar results were reported more recently for "dispersed-phase" Fe catalysts by Cugini et al. (1991)

Under appropriately selected conditions, the microemulsion-based catalysts seem to be able to produce comparable yields of oils at much lower Mo loadings. 


\section{Table 3}

Comparison of Results of Liquefaction Tests Using Conventional Catalysts and Microemulsion-Based Catalysts

\begin{tabular}{|c|c|c|c|c|}
\hline Author(s) & Coal & Conditions & Catalyst & $\begin{array}{c}\text { Yield of } \\
\text { Oils } \\
\text { (+Gas), \% }\end{array}$ \\
\hline Weller and Pelipetz (1951) & Subbit. B & $\begin{array}{l}450^{\circ} \mathrm{C}, 1 \mathrm{~h} \\
1000 \mathrm{psi} \mathrm{H} \mathrm{H}_{2}\end{array}$ & None & 10.4 \\
\hline Weller and Pelipetz (1951) & Subbit. B & $\begin{array}{l}450^{\circ} \mathrm{C}, 1 \mathrm{~h} \\
1000 \mathrm{psi} \mathrm{H}\end{array}$ & $\begin{array}{l}\text { AHM a } \\
(1 \% \mathrm{Mo}) \\
\end{array}$ & 41.1 \\
\hline Weller and Pelipetz (1951) & Subbit. B & $\begin{array}{l}450^{\circ} \mathrm{C}, 1 \mathrm{~h} \\
1000 \mathrm{psi} \mathrm{H} \mathrm{H}_{2} \\
\end{array}$ & $\begin{array}{l}\text { AHM b } \\
(1 \% \mathrm{Mo})\end{array}$ & 76.5 \\
\hline $\begin{array}{c}\text { Epstein (1987) } \\
\text { (see Burgess et al., 1991) }\end{array}$ & Subbit. B & $\begin{array}{c}425^{\circ} \mathrm{C}, 10 \mathrm{~min} \\
1000 \mathrm{psi} \mathrm{H} \\
\end{array}$ & None & 37.8 \\
\hline $\begin{array}{c}\text { Epstein (1987) } \\
\text { (see Burgess et al., 1991) } \\
\end{array}$ & Subbit. B & $\begin{array}{c}425^{\circ} \mathrm{C}, 10 \mathrm{~min} \\
1000 \mathrm{psi} \mathrm{H}_{2} \\
\end{array}$ & SAM & 24.9 \\
\hline $\begin{array}{c}\text { Epstein (1987) } \\
\text { (see Burgess et al., 1991) } \\
\end{array}$ & Subbit. B & Two-stage $c$ & None & 32.0 \\
\hline $\begin{array}{c}\text { Epstein (1987) } \\
\text { (see Burgess et al., 1991) } \\
\end{array}$ & Subbit. B & Two-stage & $\begin{array}{c}\text { SAM d } \\
(1 \% \mathrm{Mo}) \\
\end{array}$ & 44.0 \\
\hline $\begin{array}{l}\text { Burgess and Schobert } \\
\text { (see Burgess et al., 1991) }\end{array}$ & Subbit. B & $\begin{array}{c}425^{\circ} \mathrm{C}, 10 \mathrm{~min} \\
1000 \mathrm{psi} \mathrm{H}_{2} \\
\end{array}$ & None & 15.9 \\
\hline $\begin{array}{l}\text { Burgess and Schobert } \\
\text { (see Burgess et al., 1991) }\end{array}$ & Subbit. B & $\begin{array}{c}425^{\circ} \mathrm{C}, 10 \mathrm{~min} \\
1000 \mathrm{psi} \mathrm{H} \\
\end{array}$ & $\begin{array}{c}\text { SAM } \\
(1 \% \mathrm{Mo}) \\
\end{array}$ & 19.9 \\
\hline $\begin{array}{l}\text { Burgess and Schobert } \\
\text { (see Burgess et al., 1991) }\end{array}$ & Subbit. B & $\begin{array}{c}425^{\circ} \mathrm{C}, 10 \mathrm{~min} \\
1000 \mathrm{psi} \mathrm{H}_{2} \\
\end{array}$ & $\begin{array}{c}\text { STM e } \\
(1 \% \mathrm{Mo})\end{array}$ & 22.7 \\
\hline $\begin{array}{l}\text { Burgess and Schobert } \\
\text { (see Burgess et al., 1991) }\end{array}$ & Subbit. B & $\begin{array}{l}350^{\circ} \mathrm{C}, 1 \mathrm{~h} \\
1000 \mathrm{psi} \mathrm{H} \\
\end{array}$ & None & 11.2 \\
\hline $\begin{array}{l}\text { Burgess and Schobert } \\
\text { (see Burgess et al., 1991) }\end{array}$ & Subbit. B & $\begin{array}{l}350^{\circ} \mathrm{C}, 1 \mathrm{~h} \\
1000 \mathrm{psi} \mathrm{H} \\
\end{array}$ & $\begin{array}{c}\text { SAM } \\
(1 \% \mathrm{Mo}) \\
\end{array}$ & 14.0 \\
\hline $\begin{array}{l}\text { Burgess and Schobert } \\
\text { (see Burgess et al., 1991) }\end{array}$ & Subbit. B & $\begin{array}{l}350^{\circ} \mathrm{C}, 1 \mathrm{~h} \\
1000 \mathrm{psi} \mathrm{H} \\
\end{array}$ & $\begin{array}{c}\text { STM } \\
(1 \% \mathrm{Mo}) \\
\end{array}$ & 14.7 \\
\hline $\begin{array}{l}\text { Burgess and Schobert } \\
\text { (see Burgess et al., 1991) }\end{array}$ & Subbit. B & Two-stage c & None & 16.9 \\
\hline $\begin{array}{l}\text { Burgess and Schobert } \\
\text { (see Burgess et al., 1991) }\end{array}$ & Subbit. B & Two-stage & $\begin{array}{c}\text { SAM } \\
(1 \% \mathrm{Mo}) \\
\end{array}$ & 21.7 \\
\hline $\begin{array}{l}\text { Burgess and Schobert } \\
\text { (see Burgess et al., 1991) }\end{array}$ & Subbit. B & Two-stage & $\begin{array}{c}\text { STM } \\
(1 \% \mathrm{Mo}) \\
\end{array}$ & 30.7 \\
\hline
\end{tabular}


Table 3. (Continued)

\begin{tabular}{|c|c|c|c|c|}
\hline $\begin{array}{c}\text { Davis et al. (1990) } \\
\text { (see Burgess et al., 1991) }\end{array}$ & Subbit.C & $\begin{array}{c}275^{\circ} \mathrm{C}, 30 \mathrm{~min} \\
1000 \text { psi H2 } \\
\end{array}$ & None & 1.6 \\
\hline $\begin{array}{c}\text { Davis et al. (1990) } \\
\text { (see Burgess et al., 1991) }\end{array}$ & Subbit.C & $\begin{array}{c}275^{\circ} \mathrm{C}, 30 \mathrm{~min} \\
100 \mathrm{psi} \mathrm{H}_{2}\end{array}$ & $\begin{array}{l}\text { ATTM f } \\
(1 \% \mathrm{Mo}) \\
\end{array}$ & 1.5 \\
\hline $\begin{array}{c}\text { Osseo-Asare et al. } \\
\text { (1991) }\end{array}$ & Subbit. B & $\begin{array}{c}350^{\circ} \mathrm{C}, 30 \mathrm{~min} \\
1000 \mathrm{psi} \mathrm{H}_{2}\end{array}$ & $\begin{array}{c}\mathrm{AHM}^{\mathrm{AH}} \mathrm{CS}_{2} \\
(1 \% \mathrm{Mo}) \\
\end{array}$ & 70.2 \\
\hline $\begin{array}{c}\text { Osseo-Asare it }=1 . \\
\text { (1991) }\end{array}$ & Subbit. B & $\begin{array}{c}350^{\circ} \mathrm{C}, 30 \mathrm{~min} \\
1000 \mathrm{psi} \mathrm{H}_{2}\end{array}$ & $\begin{array}{c}\mathrm{NN} \mathrm{g} / \mathrm{CS}_{2} \\
(1 \% \mathrm{Fe})\end{array}$ & 74.5 \\
\hline
\end{tabular}

a $\mathrm{AHM}$ = ammonium heptamolybdate

b AHM acidified with $\mathrm{H}_{2} \mathrm{SO}_{4}$

c $350^{\circ} \mathrm{C}, 1 \mathrm{~h} ; 425^{\circ} \mathrm{C}, 10 \mathrm{~min}$

$\mathrm{d}$ SAM = sulfided ammonium molybdate

e STM = sulfided tetrahydroquinolinium molybdate

f ATTM = ammonium tetrathiomolybdate

g IN = iron nitrate 


\section{REFERENCES}

Burgess, C.E., Artok, L. and Schobert, H.H., ACS Preprints (Div. Fuel Chem.) 36 (2), 462 (1991)

Cugini, A.V., Utz, B.R., Krastman, D., Hickey, R.F. and Balsone, V., ACS Praprints (Div. Fuel Chem.) 36 (1), 91 (1991).

Hirschon, A.S. and Wilson, Jr., R.B., ACS Preprints (Div. Fuel Chem.) 36 (1), 103 (1991).

Lianus, P. and Thomas, J.K., Mater. Sci. Forum 25-26, 369 (1988).

Modes, S. and Lianos, P., J. Phys. Chem. 93, 5854 (1989).

Nagy, J.B., Coll. Surf. 35, 201 (1989).

Osseo-Asare, K., Boakye, E., Vaidyanathan, N. and Radovic, L.R., Quarterly Report to DOE, Contract No. DE-AC22-90PC90054, July 1991.

Petit, C. and Pileni, M.P., J. Phys. Chem. 92, 2282 (1988).

Solar, J.M., Leon y Leon, C.A., Osseo-Asare, K. and Radovic, L.R., Carbon 28, 369 (1990).

Towey, T.F., Khan-Lodhi, A. and Robinson, B.H., J. Chem. Soc. Faraday Trans. 86, 3757 (1990).

Utz, B.R., Cugini, A.V. and Frommell, E.A., ACS Preprints (Div. Fuel Chem.) 34 (4), 1423 (1989).

Weller, S. and Pelipetz, M.G., Ind. Eng. Chem. 43, 1243 (1951). 

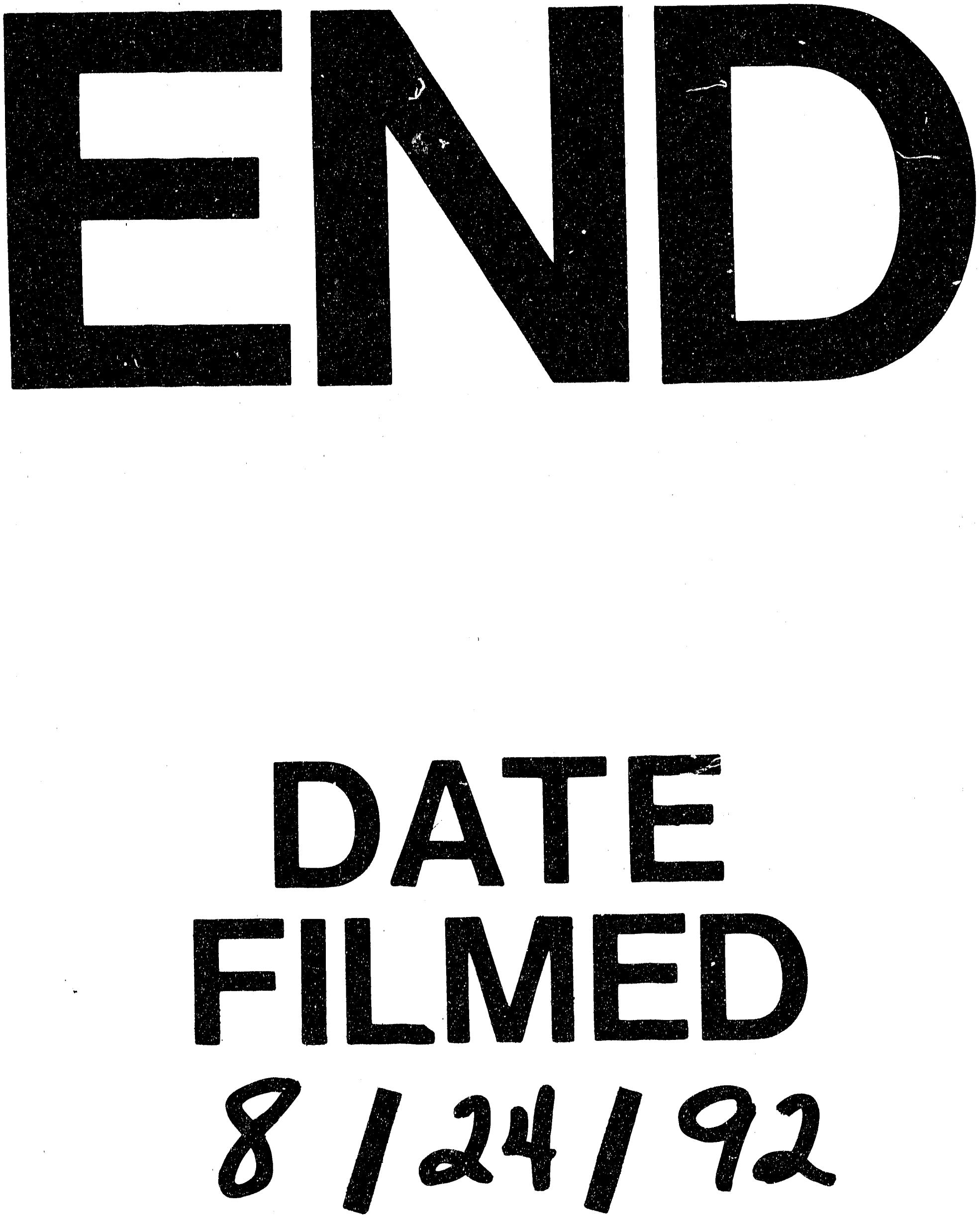